\title{
Dietary manipulation: a sustainable way to mitigate methane emissions from ruminants
}

Md Najmul Haque

\begin{abstract}
Methane emission from the enteric fermentation of ruminant livestock is a main source of greenhouse gas (GHG) emission and a major concern for global warming. Methane emission is also associated with dietary energy lose; hence, reduce feed efficiency. Due to the negative environmental impacts, methane mitigation has come forward in last few decades. To date numerous efforts were made in order to reduce methane emission from ruminants. No table mitigation approaches are rumen manipulation, alteration of rumen fermentation, modification of rumen microbial biodiversity by different means and rarely by animal manipulations. However, a comprehensive exploration for a sustainable methane mitigation approach is still lacking. Dietary modification is directly linked to changes in the rumen fermentation pattern and types of end products. Studies showed that changing fermentation pattern is one of the most effective ways of methane abatement. Desirable dietary changes provide two fold benefits i.e. improve production and reduce GHG emissions. Therefore, the aim of this review is to discuss biology of methane emission from ruminants and its mitigation through dietary manipulation.
\end{abstract}

Keywords: Diet, Starch, Sugar, Fibres, Greenhouse gas

\section{Background}

Livestock contribute to global climate change by emitting GHG either directly (from enteric fermentation and manure management) or indirectly (from feed production and the processing and converting of forest into pasture). The major GHGs from the livestock sector are carbon dioxide $\left(\mathrm{CO}_{2}\right)$, methane $\left(\mathrm{CH}_{4}\right)$ and nitrous oxide $\left(\mathrm{N}_{2} \mathrm{O}\right)$ throughout the production process (Fig. 1.1). The $\mathrm{CO}_{2}$ that is emitted from livestock is not considered a net contributor to climate change because the animals consume plants that use $\mathrm{CO}_{2}$ during photosynthesis (Steinfeld et al., 2006). Consequently, $\mathrm{CH}_{4}$ and $\mathrm{N}_{2} \mathrm{O}$ are the most important GHGs from the animal production system and have very high global warming potentials (GWP) of 25 and $298 \mathrm{CO}_{2}$ equivalent (eq), respectively [1]. The first comprehensive analysis of the environmental impact of livestock production [2] reported that approximately $18 \%$ of the global anthropogenic GHG is contributed by livestock production. The global anthropogenic GHG emissions from agriculture

\section{Correspondence: najmul471@gmail.com}

Bangabandhu Sheikh Mujibur Rahman Science and Technology University, Gopalganj 8100, Bangladesh

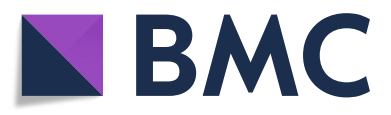

were 5.1 to 6.1 Gigatonnes $\mathrm{CO}_{2}$-eq in 2005, of which livestock shared approximately 9\% [3]. Within livestock, ruminant supply chains are the main contributors to the GHG, estimating approximately $80 \%$ of the total sector's emissions [4], while non-ruminants, e.g., pigs and poultry, contribute only approximately 9 and $8 \%$, respectively, to the sector's emissions [5]. The emissions from beef and milk production represent 35 and 30\% of the livestock sector emissions, globally. Buffalos and small ruminant supply chains have a much lower contribution, representing 8.7 and $6.7 \%$ of sector emissions, respectively [4]. Another report [5] that stated GHG emissions along livestock supply chains estimated approximately $14.5 \%$ of all human-induced emissions. Enteric fermentation and feed production related activities in ruminant production are the primary sources of GHG emissions, representing approximately 39 and $45 \%$ of the GHG of the total sector's emissions. The largest source of GHG emissions from ruminant production, i.e., $\mathrm{CH}_{4}$ derive from enteric fermentation, which accounts for approximately $47 \%$, greater than 90\% of the total $\mathrm{CH}_{4}$ emissions [4]. According to the US Environmental Protection Agency in 2009, $\mathrm{CH}_{4}$ emissions

(c) The Author(s). 2018 Open Access This article is distributed under the terms of the Creative Commons Attribution 4.0 International License (http://creativecommons.org/licenses/by/4.0/), which permits unrestricted use, distribution, and reproduction in any medium, provided you give appropriate credit to the original author(s) and the source, provide a link to the Creative Commons license, and indicate if changes were made. The Creative Commons Public Domain Dedication waiver (http://creativecommons.org/publicdomain/zero/1.0/) applies to the data made available in this article, unless otherwise stated. 
Feed

(carbohydrate polymer)

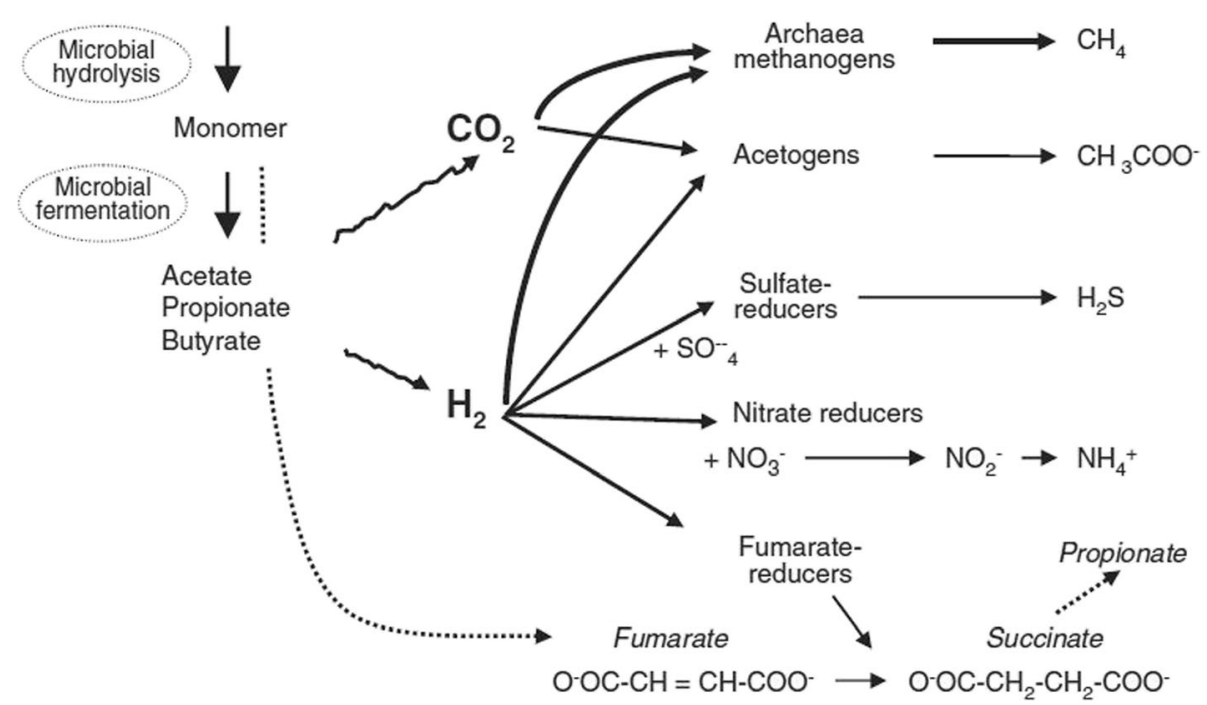

Fig. 1 Schematic microbial fermentation and the $\mathrm{H}_{2}$ reduction pathway in the rumen [15]

from enteric fermentation represented approximately $20 \%$ of total $\mathrm{CH}_{4}$ emissions from anthropogenic sources [6]. The rate of emission in terms of carbon footprint at the product levels is $2.8,3.4$ and $6.5 \mathrm{~kg} \mathrm{CO}$-eq/ $\mathrm{kg}$ FPCM for milk production from dairy cattle, buffalo and small ruminants, respectively. However, with regard to meat from ruminants, the carbon footprint for beef, buffalo meat and small ruminant meat is $46.2,53.4$ and $23.8 \mathrm{~kg} \mathrm{CO}$-eq $/ \mathrm{kg}$ meat, respectively [4]. According to the values that were projected by EPA [7], the direct non- $\mathrm{CO}_{2}$ emissions from livestock would be approximately 7.3 to $7.5 \%$ of the global GHG emissions between 2010 and 2020, respectively. Ruminant production faces difficult challenges and must reduce GHG emission while responding to the significant demand of livestock products (projected $+70 \%$ by 2050 for a world-projected population of 9.6 billion) [5]. The global food demand will also increase with the rapidly increasing global population. Consequently, the demand for animal products will also increase. Therefore, the environmental impact per unit of animal products will obviously be increased. Thus, the sector will be vulnerable in terms of environmental sustainability. Therefore, sustainable and immediate mitigation strategies are in high demand. This review will focus on $\mathrm{CH}_{4}$ mitigation from ruminants through dietary manipulation.

\section{Methanogenesis and methane production in the rumen}

Methanogenesis is a process of $\mathrm{CH}_{4}$ production in the rumen where $\mathrm{H}_{2}$ reduced the $\mathrm{CO}_{2}$ with the help of methanogenic archaea. This is a dynamic process, in which methanogens strongly influence the metabolism of fermentative and acetogenic bacteria via interspecies hydrogen transfer [8]. The carbohydrate fraction of the feed constitutes structural plant fibre that has been degraded by a consortium of rumen microbes under anaerobic conditions with the production of volatile fatty acids (VFA), $\mathrm{CO}_{2}$ and $\mathrm{H}_{2}$ (summarised in Table). During fermentation, hydrogen $\left(\mathrm{H}_{2}\right)$ is released into the rumen via the re-oxidation of the reduced cofactors $(\mathrm{NADH}$, NADPH and FADH). The produced $\mathrm{H}_{2}$ and $\mathrm{CO}_{2}$ are the major substrates that are used by methanogens, which is considered being the predominant pathway of $\mathrm{CH}_{4}$ production in the rumen [9]. Methane production from $\mathrm{H}_{2}$ and $\mathrm{CO}_{2}$ reduces the partial pressure of $\mathrm{H}_{2}$, thereby favouring continued fermentation [9]. Without the removal of $\mathrm{H}_{2}$, the further re-oxidation of reduced cofactors (NADH, NADPH and FADH) would be inhibited by the accumulation of $\mathrm{H}_{2}$, consequently inhibiting the production of VFA (Table 1) [10].

In addition, the functional group of methanogens also uses formate, acetate, methanol, methylamines (mono-, di- and trimethylamine) and alcohol [9] as presented in Fig. 1. Formate is used by many of hydrogenotrophic rumen methanogens as an alternative to $\mathrm{H}_{2}$ [11], accounting for up to $18 \%$ of the total $\mathrm{CH}_{4}$ production in the rumen [12]. Acetate is highly available in the rumen environment, but acetoclastic methanogenesis bears very limited importance in the rumen system [13] because the acetate-utilising methanogen Methanosarcinales has a very low growth rate and is consequently flushed from the ruminants digestive system [14]. Furthermore, acetogens have a lower affinity to $\mathrm{H}_{2}$ [15]. Other substrates, including methylamine and methanol, have been investigated for $\mathrm{CH}_{4}$ production in the rumen. The methyl 
Table 1 Volatile fatty acids production (VFA) and reductive process in the rumen adopted from [95, 96]

\begin{tabular}{|c|c|c|c|c|}
\hline$\underline{\text { Substrate }}$ & & Products & $\Delta \mathrm{G}(\mathrm{KJ})^{1}$ & Reactions \\
\hline \multicolumn{5}{|l|}{ VFA production } \\
\hline $\mathrm{C}_{6} \mathrm{H}_{12} \mathrm{O}_{6}+2 \mathrm{H}_{2} \mathrm{O}$ & $\rightarrow$ & $2 \mathrm{C}_{2} \mathrm{H}_{4} \mathrm{O}_{2}+2 \mathrm{CO}_{2}+8 \mathrm{H}^{+}$ & & Acetate production \\
\hline $\mathrm{C}_{6} \mathrm{H}_{12} \mathrm{O}_{6}+4 \mathrm{H}^{+}$ & $\rightarrow$ & $2 \mathrm{C}_{3} \mathrm{H}_{6} \mathrm{O}_{3}+2 \mathrm{H}_{2} \mathrm{O}$ & & Propionate production \\
\hline $\mathrm{C}_{6} \mathrm{H}_{12} \mathrm{O}_{6}$ & $\rightarrow$ & $\mathrm{C}_{4} \mathrm{H}_{8} \mathrm{O}_{4}+2 \mathrm{CO}_{2}+4 \mathrm{H}^{+}$ & & Butyrate production \\
\hline \multicolumn{5}{|l|}{ Reductive process } \\
\hline $\mathrm{CO}_{2}+4 \mathrm{H}_{2}$ & $\rightarrow$ & $\mathrm{CH}_{4}+2 \mathrm{H}_{2} \mathrm{O}$ & -67.4 & Methane production \\
\hline $2 \mathrm{CO}_{2}+4 \mathrm{H}_{2}$ & $\rightarrow$ & $\mathrm{C}_{2} \mathrm{H}_{4} \mathrm{O}_{2}+2 \mathrm{H}_{2} \mathrm{O}$ & -8.8 & Reductive acetogenesis \\
\hline $\mathrm{SO}_{4}^{2-}+4 \mathrm{H}_{2}+\mathrm{H}^{+}$ & $\rightarrow$ & $\mathrm{HS}^{-}+4 \mathrm{H}_{2} \mathrm{O}$ & -84.4 & Sulfate reduction \\
\hline $\mathrm{NO}_{3}^{-}+4 \mathrm{H}_{2}+2 \mathrm{H}^{+}$ & $\rightarrow$ & $\mathrm{NH}_{4}+3 \mathrm{H}_{2} \mathrm{O}$ & -371 & Nitrate reduction \\
\hline
\end{tabular}

${ }^{1}$ under following rumen conditions: $\mathrm{H}_{2}=162 \mathrm{pa} ; \mathrm{pH}=6.5 ;\left[\mathrm{H}_{2} \mathrm{O}\right]=50 \mathrm{M} ;\left[\right.$ succinate $\left.{ }^{2-}\right]=4 \times 10^{-6} \mathrm{M} ;\left[\right.$ malate $\left.{ }^{2-}\right]=[\beta-$ hydroxybutyryl-CoA $]=[$ butyryl-CoA $]=10^{-6} \mathrm{M}$; [acetate $\left.{ }^{-}\right]=70 \mathrm{mM}$; [propionate $\left.{ }^{-}\right]=25 \mathrm{mM}$; [butyrate $\left.{ }^{-}\right]=15 \mathrm{mM} ;\left[\right.$ lactate $\left.{ }^{-}\right]=1 \mathrm{mM} ;\left[\mathrm{NH}_{4}^{+}\right]=11 \mathrm{mM}\left(20 \mathrm{mg} / \mathrm{dL}^{+} ;\left[\mathrm{HS}^{-}\right]=0.14 \mathrm{mM}^{-} \Delta \mathrm{G}=\right.$ free energy change indicates how energetically favourable it is i.e. the higher $\Delta \mathrm{G}$, the more energy utilization and negative $\Delta \mathrm{G}$ indicates the energy release

group is rapid converted by the rumen microorganisms to trimethylamine via di- and monomethylamine and is possibly used for $\mathrm{CH}_{4}$ production [16]. However, only Methylotrophic methanogens within the order Methanosphaera spp. use methanol for $\mathrm{CH}_{4}$ production [13].

Because neither of these microbes are abundant in the rumen [17], the contribution of these substrates to total $\mathrm{CH}_{4}$ production is expected to be lower [15]. Consequently, the most favourable $\mathrm{CH}_{4}$ production pathway in ruminants is the product of $\mathrm{H}_{2}$ oxidation using $\mathrm{CO}_{2}$ as an external electron acceptor [9].

\section{Methane mitigation strategies}

Methane is expected to contribute approximately $18 \%$ of the total expected global warming within the next 50 years [18], of which the contribution of livestock to the total global emission is approximately 9\% [3]. Domestic animals account approximately $94 \%$ of the total global emissions of animals [18]. Although emissions have decreased per unit of animal product, the total emission has increased from a vast animal population around the globe [4]. By 2050, the total $\mathrm{CH}_{4}$ emission from ruminant livestock is expected to increase significantly due to the growing demand of milk and meat for a rapidly growing world population [5]. Therefore, it is of utmost importance to mitigate $\mathrm{CH}_{4}$ emission from the livestock industry. There are several strategies for $\mathrm{CH}_{4}$ mitigation from ruminants that have recently been reviewed [19-21].

\section{Dietary manipulation}

Among the nutritional strategies of $\mathrm{CH}_{4}$ mitigation, dietary manipulation is a simplistic and pragmatic approach that can ensure better animal productivity as well as a lower $\mathrm{CH}_{4}$ emission. The schematic diagram of dietary manipulation, which alters the pathway of fermentation to reduce $\mathrm{CH}_{4}$, is summarised in Fig. 2 .

Dietary manipulation can reduce $\mathrm{CH}_{4}$ emission up to $40 \%$ depending the degree of change and the nature of the intervention [22]. Another study also indicated that $\mathrm{CH}_{4}$ emissions can possibly be reduced up to $75 \%$ through better nutrition [23]. However, dietary manipulation is the most commonly practiced approach. Dietary strategies can be divided into two main categories: i) improving the forage quality and changing the proportion of the diet and ii) dietary supplementation of feed additives that either directly inhibit methanogens or altering the metabolic pathways leading to a reduction of the substrate for methanogenesis.

\section{Forage}

Forage quality has influences $\mathrm{CH}_{4}$ production in the rumen [24]. High-quality forage, e.g., young plants, can reduce $\mathrm{CH}_{4}$ production by altering the fermentation pathway because this forage contains higher amounts of easily fermentable carbohydrates and less NDF, leading to a higher digestibility and passage rate [25]. In contrast, more mature forage induces a higher $\mathrm{CH}_{4}$ yield mainly due to an increased $\mathrm{C}: \mathrm{N}$ ratio, which decreases the digestibility [18]. Different types of forage can also affect $\mathrm{CH}_{4}$ emission due to the differences in their chemical composition [22]. However, Hammond, Burke [26] found an inconsistent effect of the chemical composition of white clover and ryegrass on $\mathrm{CH}_{4}$ production. Legume forage has a lower $\mathrm{CH}_{4}$ yield, which is explained by the presence of condensed tannins, a low fibre content, a high dry matter intake and a fast passage rate [19]. Generally, C4 grasses yield more $\mathrm{CH}_{4}$ than the $\mathrm{C} 3$ plants [27]. Forage processing and preservation also affect $\mathrm{CH}_{4}$ emission [21]. For instance chopping or pelleting forages can reduce the $\mathrm{CH}_{4}$ emission per $\mathrm{kg}$ of DMI, as smaller particles require less degradation in the rumen [28]. Methanogenesis tends to be lower in the ensiled forages [28], presumably because the ensiled forages are already partially fermented during the ensiling process. Feeding improves the forage quality by feeding young forage with a lower fibre content and a 


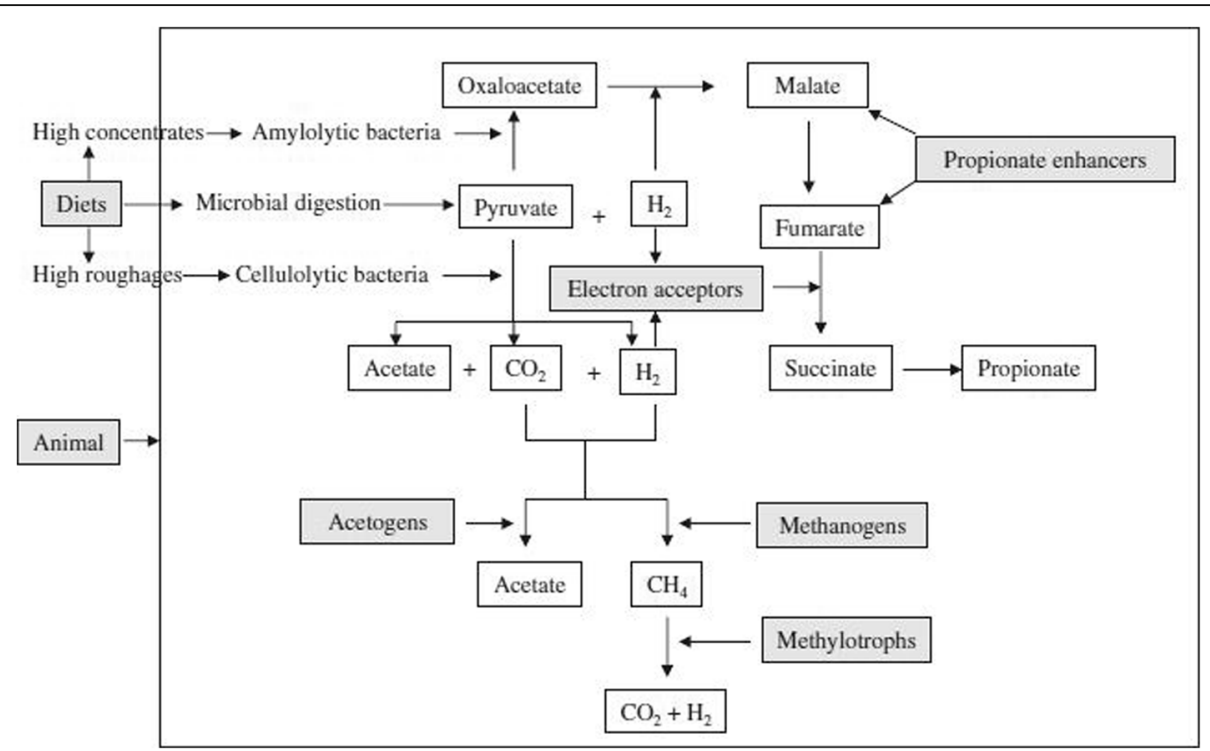

Fig. 2 Target points (marked grey) at which dietary manipulation alters the fermentation pathway to reduce $\mathrm{CH}_{4}$ in the rumen [62]

higher soluble carbohydrate content; supplementing a small amount of grain with forage is a promising mitigation approach.

\section{Replacement of grass silage by maize silage}

Grass silage is usually harvested at a later stage of maturity, resulting in a lower content of digestible organic matter, lower sugar and nitrogen contents and a fraction of lactate as a result of the ensiling process [29]. Consequently, the $\mathrm{CH}_{4}$ emission from animals that are fed grass silage is likely to be higher. In contrast, maize silage or other whole-crop small-grain silage typically provides higher contents of dry matter with readily digestible carbohydrates, e.g., starch, increasing the DMI and animal performance [19] and ultimately resulting in a lower $\mathrm{CH}_{4}$ yield from animals. There are three possible ways by which maize silage or whole-crop silage can reduce $\mathrm{CH}_{4}$ production in the rumen. First, the higher starch content favours propionate production rather than acetate. Second, the increased total DMI and passage rate reduce the ruminal residence time, thereby reducing ruminal fermentation and promoting post-ruminal digestion. Third, replacing grass silage with maize silage improves animal performance, resulting in fewer $\mathrm{CH}_{4}$ emissions per unit of animal product [30]. Several recent studies have indicated the positive effects of replacing grass silage with maize silage. Hassanat, Gervais [31] reported lower $\mathrm{CH}_{4}$ emission when alfalfa silage is replaced by $100 \%$ corn silage. Maize silage that is harvested during the later stage of maturity has also claimed to reduce $\mathrm{CH}_{4}$ [29].

\section{Concentrates}

High-producing dairy cows have a higher requirement that exceeds their capacity to ingest nutrients from forage only. Therefore, forages must be supplemented with concentrates with a higher density of nutrients and less fibre. Due to less cell walls and readily fermentable carbohydrates (starch and sugar), concentrates favour propionic acid production, decreasing $\mathrm{CH}_{4}$ emission [21]. The $\mathrm{CH}_{4}$ reduction effect of concentrates can be described in two ways as below.

\section{Proportion of concentrate}

The increased dietary level of concentrate reduces $\mathrm{CH}_{4}$ production as the energy proportion is mostly utilised by the animal products, such as milk and meat [21]. This effect is independent of genetic merit [32]. Decreased $\mathrm{CH}_{4}$ emission was observed at 80 and $90 \%$ concentrate supplementation, whereas no effect was found at 35 or $60 \%$ concentrate supplementation [33]. Most energy-rich concentrates are associated with increased DMI, rate of rumen fermentation and feed-turnover rate, causing a greater change in the rumen environment and microbial composition [21]. An extremely low $\mathrm{CH}_{4}$ loss of $2-3 \%$ of the gross energy intake was reported for feedlot cattle that were fed diet a 90\% concentrate [34]. However, high-concentrate diets are low in structural fibre and in the long term disturb rumen function by leading to sub-acute or acute acidosis; therefore, these diets are not sustainable for ruminant production. Feeding concentrate with a suitable $\mathrm{F}: \mathrm{C}$ ration would obviously be effective in methane mitigation as well as animal productivity. 


\section{Concentrate composition}

Concentrates that are composed of different ingredients have variable carbohydrate compositions, ranging from structural (cellulose and hemicellulose) to non-structural (starch and sugar) carbohydrates. The degradable rate of both of these types of carbohydrates also varies widely according to the volatile fatty acid profile and $\mathrm{CH}_{4}$ loss. In beef cattle [34], the digestion of the cell wall leads to a higher acetate: propionate ratio and $\mathrm{CH}_{4}$ loss compared to other carbohydrate fraction; within non-structural components, sugar is more methanogenic than starch. All of the carbohydrate fractions contribute to $\mathrm{CH}_{4}$ loss, of which the least contribution is that from starch, probably due to the maintenance of a propionate-dominating VFA profile [29]. Feeding more starch to ruminants reduces enteric $\mathrm{CH}_{4}$ energy losses compared to feeding a forage diet [35]. Starch fermentation promotes propionate production in the rumen by creating an alternative $\mathrm{H}_{2}$ sink [36], a lower rumen $\mathrm{pH}$, inhibiting the growth of methanogens [37], decreasing the rumen protozoan numbers and limiting the interspecies $\mathrm{H}_{2}$ transfer between methanogens and protozoa [38]. In addition, feeding starch, which can escape rumen fermentation, could potentially supply energy to the host animals while avoiding methanogenesis in the rumen. Up to $30 \%$ of the starch from corn can escape rumen fermentation and be digested in the small intestine [39]. However, the bypass starch has limited digestibility (up to 60\%) in the small intestine [40]. Very limited results are available on the effects of bypass starch on methane mitigation. Further investigation is required for detailed information.

In contrast, sugar as a water-soluble carbohydrate is rapidly and completely degradable in the rumen, enhancing butyrate production at the expense of propionate, thereby making sugar concentrates more methanogenic than starch [41]. Sugars enhance butyrate production at a higher $\mathrm{H}_{2}$ partial pressure and higher rumen $\mathrm{pH}$, as confirmed by Hindrichsen and Kreuzer [42], who reported a $40 \%$ higher $\mathrm{CH}_{4}$ production with sucrose at a high $\mathrm{pH}$ compared to starch, while the opposite result was observed at a low $\mathrm{pH}$ with a significantly lower $\mathrm{pH}$ for sucrose.

\section{Fat supplementation}

The addition of fat to the diet has traditionally been used to increase the dietary energy content to meet the energy demand of high-producing dairy cows. More recently, fat has been used for $\mathrm{CH}_{4}$ mitigation. If the energy supplementation in a ruminant's diet is changed from carbohydrate to fat, then less fermentation and $\mathrm{CH}_{4}$ production will occur. The $\mathrm{CH}_{4}$-suppressing mechanism of fat is induced by reducing organic matter fermentation, fibre digestibility and consequently the methanogenic pathway and by the direct inhibition of methanogens in the rumen via the hydrogenation of unsaturated fatty acids [34]. The greatest reduction comes from the unsaturated fatty acids, which act as an $\mathrm{H}_{2}$ sink in the rumen through dehydrogenation [43], although other studies have reported that hydrogenation contributes only $1 \%$ of the $\mathrm{H}_{2}$ in the rumen [44]. Among fatty acids, the medium-chain $\mathrm{C}_{8}: \mathrm{C}_{14}$ from coconut or palm oil is the most effective in $\mathrm{CH}_{4}$ mitigation. Furthermore, fats are not metabolised in the rumen [45] and therefore do not contribute to methanogenesis [34]. Grainger and Beauchemin [46] also reported that fat supplementation often reduces carbohydrate fermentation due to the toxic effects of fat on cellulolytic bacteria and protozoa, while starch fermentation remains unaffected. Consequently, fat depresses $\mathrm{CH}_{4}$ emission [47]. However, fat supplementation to the ruminant diet is a persistent mitigation strategy [46].

\section{Organic acids}

The addition of organic acids, the intermediates of carbohydrate degradation, to the rumen has been suggested as potential feed additives for $\mathrm{CH}_{4}$ mitigation. Organic acids probably stimulate propionic acid production in the rumen by acting as an $\mathrm{H}_{2}$ sink, thereby reducing the amount of $\mathrm{CH}_{4}$ [48]. Newbold, Lopez [49] tested 15 propionate precursors in vitro and concluded that the structure appears to be more effective as an $\mathrm{H}_{2}$ sink that can reduce $\mathrm{CH}_{4}$ up to $17 \%$. Fumarate and acrylate produce the most consistent reductions in $\mathrm{CH}_{4}$ formation in batch cultures, while fumarate is more effective than acrylate in artificial rumens [50]. Furthermore, fumarate $(3.5 \mathrm{~g} / \mathrm{L})$ reduces the $\mathrm{CH}_{4}$ output by $38 \%$ in continuous fermenters using forage as a substrate [51]. However, a meta-analysis [52] reported a lower $\mathrm{CH}_{4}$ reduction effect in a continuous batch culture. Including multiple forms of propionate precursors in the diet yielded an additive inhibition of $\mathrm{CH}_{4}$ emissions as the reductive pathways differ among organic acid sources [50]. In contrast, an in vivo study with growing beef cattle reported a potential beneficial change in rumen fermentation by fumarate, although $\mathrm{CH}_{4}$ reduction was unaffected [53]. Organic acid supplementation has mostly been tested for $\mathrm{CH}_{4}$ production in vitro, producing inconsistent results. Therefore, there is the potential to invest more research in farm animals.

\section{Essential oils}

Essential oils are plant secondary metabolites, volatile components [29] and aromatic lipophilic compounds [54] with very strong antimicrobial properties [55], which inhibit the growth and survival of most of microorganisms in rumen [56]. The mode of action varies in individual essential oils [57]. However, all essential oils contain chemical constituents and functional groups, such as terpenoids, phenolic and phenols, which have strong antimicrobial properties. Because of their lipophilic nature, essential oils have a high affinity for microbial cell membranes, and functional 
groups interact with the microbial cell membrane [58]. Methanogenesis decreases with the application of essential oil, especially by reducing microbial populations. However, no effect has been observed so far on the major aspects of rumen fermentation [59]. Limited studies have investigated the effect on $\mathrm{CH}_{4}$ reduction in vivo. However, methanogenesis is inhibited by altering protein degradation and amino acid determination [59]. Further research needs to investigate the potential use of essential oils in mainstream livestock farming.

\section{lonophores}

Antibiotics, such as monensin, are antimicrobial compounds that are typically used in beef and dairy cattle production to modulate feed intake and improve feed efficiency and animal productivity [60]. Monensin increases the acetate: propionate ratio in rumen fermentation by increasing reducing equivalents that help to form propionate [19]. Monensin may also decrease ruminal protozoa. This antibiotic is typically added to the diet as premix or via a slow-releasing capsule and has an anti-methanogenic effect [19]. Ionophores do not alter the diversity of methanogens [61] but change the bacterial population from Gram-positive to Gram-negative with a consequent change in the fermentation from acetate to propionate, thereby reducing $\mathrm{CH}_{4}$ [62]. A high dose of monensin reduces $\mathrm{CH}_{4}$ production $(\mathrm{g} / \mathrm{d})$ by $4-$ $10 \%$ in dairy and beef cattle $[63,64]$. Furthermore, Guan, Wittenberg [65] reported a $30 \% \mathrm{CH}_{4}$ reduction in beef cattle that were fed monensin $(33 \mathrm{mg} / \mathrm{kg})$, which was related to the number of ciliated protozoa. The inhibitory effects of ionophores on $\mathrm{CH}_{4}$ production may not persist over time, and microorganisms adapt to ionophores [19, $34,65]$. However, the possible transient effect of ionophores and increasing public pressure to reduce the use of antimicrobial feed additives in agricultural production will obviously limit the scope for a long-term solution to $\mathrm{CH}_{4}$ mitigation [19].

\section{Probiotics}

The use of probiotics for $\mathrm{CH}_{4}$ mitigation has recently been described [66]; [43]. The specific $\mathrm{CH}_{4}$ reduction potential of probiotics has not been well documented due to the unsuccessful introduction of acetogens to the rumen as competitors of methanogens [67]. Probiotics, such as lactic acid producers (Lactobacillus plantarum, L. casei, L. acidophilus and Enterococcus faecium), acetate and propionate producers (Selenomonas ruminantium and Megasphaera elsdenii) and yeast (Saccharomyces cerevisiae and Aspergillus oryzae) are widely used for the health of both human and animals [68]. Probiotics based on Saccharomyces cerevisiae are increasingly used in ruminant diets to improve rumen fermentation, dry matter intake and milk yield [19]. The underlying mechanism is probably the alteration of
$\mathrm{H}_{2}$ production by the increased number of bacteria due to the partitioning of degraded carbohydrates between the microbial cells and fermented products [69]. Due to their modest price and wide use in ruminant production, the acceptance of $\mathrm{CH}_{4}$-reducing probiotics has a high probability in $\mathrm{CH}_{4}$ abatement. However, further research is needed to investigate the best possible products [19].

\section{Exogenous enzymes}

Enzymes, such as cellulase and hemicellulase, are currently being used in ruminant diets. When properly formulated, enzymes can improve fibre digestibility and animal productivity [70]. Enzymes that improve fibre digestibility typically lower the acetate: propionate ratio in the rumen, ultimately reducing $\mathrm{CH}_{4}$ production [71]. Subsequently, in a recent review, Beauchemin, Kreuzer [19] suggested the possibility of developing a commercial enzyme additive to reduce $\mathrm{CH}_{4}$. However, searching for potential enzymes for methane abatement warrants future research.

\section{Alternative $\mathrm{H}_{2}$ sink}

Alternative $\mathrm{H}_{2}$ sinks, for example, nitrate and sulphate, are used at lower concentrations in the basic diets of ruminants. As alternative electron acceptors, nitrate and sulphate have a greater reduction potential and are thermodynamically highly favourable for some rumen microbes [72]. Regarding methane mitigation, Leng [73] described the potential of nitrate supplementation in the ruminant diet. Furthermore, van Zijderveld, Gerrits [74] demonstrated that the reduction effect of nitrate and sulphate is electronically more favourable than is $\mathrm{CH}_{4}$ production, which can potentially change the competitiveness of $\mathrm{H}_{2}$ scavengers. In recent years, nitrate and sulphate have been increasingly tested for $\mathrm{CH}_{4}$ abatement. A 32\% methane reduction was reported for nitrate, $16 \%$ for sulphate and $47 \%$ for a combination of nitrate and sulphate fed to lambs [74]. The same author in a subsequent study indicated an approximately $16 \% \mathrm{CH}_{4}(\mathrm{~g} / \mathrm{d}$ and g/kg DMI) reduction in dairy cows [75]. However, nitrate supplementation has not been established in many countries (e.g., in Denmark) due to toxic effects that could lead to animal death. One potential toxic effect occurs via the reduction of nitrate to nitrite, which causes methemoglobinemia, a condition in which blood haemoglobin cannot carry oxygen [74]. Because a lower amount of nitrate in the diet is safe for the animal [76], nitrate supplementation can be an effective $\mathrm{CH}_{4}$ mitigation measure. However, more research is needed to determine the inclusion levels for different ruminant species.

\section{Plant secondary metabolites}

The potential effect of plant secondary metabolites (PSM) in $\mathrm{CH}_{4}$ reduction has been recently recognised [19]. The $\mathrm{CH}_{4}$-suppressing effect of PSM is mainly 
associated with antimicrobial properties that kill the bacteria [77], protozoa [78] and fungi [79] in the rumen. Plant secondary metabolites contain phenolic compounds the main active components that have antimicrobial activity [80]. Plants produce a variety of secondary compounds, among which condensed tannins [81] and saponins [82] have received much attention.

\section{Condensed tannins}

An interesting development in $\mathrm{CH}_{4}$ mitigation research is the development of forages with higher levels of tannins, such as clover and other legumes, including trefoil, vetch, sulla and chicory [29]. The anti-methanogenic activity of tannins has recently been investigated in vitro and in vivo [83]. The $\mathrm{CH}_{4}$-suppressing mechanism of tannins has not been described clearly; however, this mechanism may inhibit ruminal microorganisms [77]. Tannins may inhibit, through bactericidal or bacteriostatic activities, the growth or activity of rumen methanogens and protozoa [84]. Methane production was reduced (up to 55\%) when ruminants were fed tannin-rich forages, such as lucerne, sulla, red clover, chicory and lotus [81]. Although tannins appear promising for $\mathrm{CH}_{4}$ mitigation, these impede forage digestibility and animal productivity when fed at a higher concentration, limiting their future wide-scale use in $\mathrm{CH}_{4}$ abatement [19]. However, more research may identify the balance between $\mathrm{CH}_{4}$ reduction and possible anti-nutritional side effects as associated with tannin supplementation.

\section{Saponins}

Saponins are naturally occurring surface-active glycosides that are found in a wide variety of cultivated and wild plant species that reduce $\mathrm{CH}_{4}$ production in the rumen $[29,79]$. Saponins have a potent antiprotozoal activity by forming complex sterols in protozoan cell membranes [83] and, to some extent, exhibit bacteriolytic activity in the rumen [66]. Saponins are antiprotozoal at lower concentrations [85], whereas higher concentrations can suppress methanogens [77]. Saponins inhibit ruminal bacterial and fungal species [79] and limit the $\mathrm{H}_{2}$ availability for methanogenesis in the rumen, thereby reducing $\mathrm{CH}_{4}$ production [77]. Methane reduction of up to $50 \%$ has been reported with the addition of saponins [86]. However, a wider range of $\mathrm{CH}_{4}$ reduction (14-96\% depending on the plant and the solvent that was used for extraction) has been reported [62].

\section{Rumen manipulation}

Manipulating the microbial diversity in the rumen through chemical means (e.g., halogenated compounds and chloroform) by introducing competitive or predatory microbes or through direct immunisation can reduce methanogenesis in ruminants [20]. A preliminary study suggested that vaccination against methanogens can reduce $\mathrm{CH}_{4}$ emission up to $8 \%$ [87]. However, the long-term effect of vaccination on $\mathrm{CH}_{4}$ reduction is still uncertain [88]. Furthermore, methanogen populations in the rumen are influenced by diet and geographic location (Wright et al., 2007); therefore, it is challenging to develop a broad-spectrum vaccine against all methanogens. Instead, the development of a vaccine against the cell-surface proteins of methanogens may improve the efficacy of vaccination for $\mathrm{CH}_{4}$ mitigation [50]. Biological control bacteriophages or bacteriocins could be effective in the direct inhibition of methanogens and in redirecting $\mathrm{H}_{2}$ to other reductive rumen microbes, such as propionate producers or acetogens [50]. However, most of these options are still conceptual, and significant research is required.

Halogenated compounds, such as bromochloromethane and chloroform, are potent inhibitors of $\mathrm{CH}_{4}$ production in ruminants. Methane reduction has been reported with bromochloromethane mainly due to the reduction of methanogen abundance [89]. An approximately $26 \% \mathrm{CH}_{4}$ reduction was reported by McAllister and Newbold [50] through the chemical inhibition of protozoa because the methanogens are often attached to the surface or endosymbionts within ciliated protozoa [50].

Defaunation also reduces $\mathrm{CH}_{4}$ emission. Two major advantages of defaunation are that it increases nutrient utilisation by animals and limits $\mathrm{H}_{2}$ transfer between protozoa and methanogens. The methanogens that are attached to ciliated protozoa contribute approximately 9-37\% of the methanogenesis in the rumen [38]. Protozoa-free lambs and sheep exhibits 26 and $20 \% \mathrm{CH}_{4}$ reduction, respectively [50]. The elimination of the protozoan population in $\mathrm{CH}_{4}$ mitigation is interesting, but the absence of protozoa in the rumen can hinder digestibility and animal performance.

Reductive acetogenesis, in which $\mathrm{H}_{2}$ and $\mathrm{CO}_{2}$ form acetate rather than $\mathrm{CH}_{4}$ as a source of energy, has been suggested as an alternative to methanogenesis [90]. The production of acetate instead of $\mathrm{CH}_{4}$ can increase the energy supply to the animals. Joblin [90] suggested that if the $\mathrm{CH}_{4}$ emissions in ruminant were fully replaced by acetate, this could represent an energetic gain of 4-15\%. However, acetogenesis in $\mathrm{CH}_{4}$ reduction has not been successful due to the failure in acetogens competing for $\mathrm{H}_{2}$ in the rumen. Research in acetogenesis as a $\mathrm{CH}_{4}$ mitigation measure is still in the initial phase and warrant more research.

\section{Animal manipulation}

Several options, such as culling low-producing animals, increasing animal productivity and breeding animals with lower $\mathrm{CH}_{4}$, have been suggested for $\mathrm{CH}_{4}$ mitigation through animal manipulation. Methane emission is directly proportional to the number of animals in a herd. The 
replacement of non-productive and low-producing animals would cut the total $\mathrm{CH}_{4}$ budget from the herd. Maintaining high-producing animals will increase the total production, but the $\mathrm{CH}_{4}$ emission per unit of animal product will decrease [62, 91]. Therefore, proper nutrition management to improve productivity is an option to reduce the $\mathrm{CH}_{4}$ emission per unit of animal product.

Several studies have demonstrated a substantial variation in $\mathrm{CH}_{4}$ production in sheep and cows [92-94], which may be linked to phenotypic traits and heritability. This animal variation in $\mathrm{CH}_{4}$ production suggests a possibility of breeding animals with low $\mathrm{CH}_{4}$ emission. However, Eckard, Grainger [20] suggested that breeding for reduce $\mathrm{CH}_{4}$ production is unlikely to be compatible with other breeding objectives.

\section{Conclusions}

A Number of methane mitigation options are available and currently in practice. No single option appears to provide a simple and enduring solution. Selection and breeding of low methane emitter animals is one of the solutions which requires longer time frame. Use of chemicals, ionophors, plant secondary metabolites or such application attributes transitory effects on methane reduction. However, overall dietary manipulation by selecting and utilizing high quality forages, strategic supplementation of forages, changing concentrate proportion with special emphasis on changing carbohydrate composition should be considered as an immediate and sustainable methane mitigation approach of enteric $\mathrm{CH}_{4}$ emitted from ruminant livestock. Feeding a diet with more starch and less fibres not only produce less methane per $\mathrm{kg}$ feed DM but also form a basis for higher feed intake and higher production per animal and hence will be the most efficient way to reduce the methane production per $\mathrm{kg}$ of meat or milk produced.

\section{Abbreviations}

GHG: Greenhouse gas; $\mathrm{CO}_{2}$ : Carbon dioxide; $\mathrm{CH}_{4}$ : Methane; $\mathrm{N}_{2} \mathrm{O}$ : Nitrous oxide; GWP: Global warming potential; FPCM: Fat and protein corrected milk; DMI: Dry matter Intake; $\mathrm{H}_{2}$ : Hydrogen; VFA: Volatile fatty acid

\section{Acknowledgements}

The authors would like to acknowledge Jorgen Madsen, Professor (retired) for his kind instruction to prepare this review.

\section{Availability of data and materials}

Data sharing not applicable to this article as no datasets were generated or analysed during the current study.

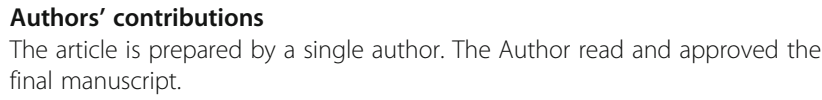

Ethics approval and consent to participate Not applicable.

\section{Competing interests}

The author declares that he/she has no competing interests.

\section{Publisher's Note}

Springer Nature remains neutral with regard to jurisdictional claims in published maps and institutional affiliations.

Received: 28 November 2017 Accepted: 4 June 2018

Published online: 18 June 2018

\section{References}

1. Solomon S, Qin D, Manning M. Technical summary. In: Solomon S, Qin D, Manning M, Marquis M, Averyt K, Tignor MMB, Miller HL, Chen ZL, editors. Climate change 2007. The physical science basis. Contribution of working group $i$ to the fourth assessment report of the intergovernmental panel on climate change. United Kingdom and New York, NY, USA: Cambridge University Press, Cambridge; 2007. p. 19-91.

2. Steinfeld H, Gerber P, Wassenaar T, Castel V, Rosales M, Haan CD. Livestock's long shadow: Environmental issues and options. Rome, Italy: Food and Agriculture Organization of the United Nations (FAO); 2006.

3. IPCC, Climate change 2007. In: Mertz B, Davidson OR, Bosch PR, et al., editors. Mitigation. Contribution of working group iii to the fourth assessment report of the intergovernmental panel on climate change. United Kingdom and New York, NY, USA: Cambridge University Press, Cambridge; 2007.

4. Opio C, Gerber P, Mottet A, Falcucci A, Tempio G, MacLeod M, Vellinga T, Henderson B, Steinfeld H. Greenhouse gas emissions from ruminant supply chains - a global life cycle assessment. Rome, Italy: Food and Agriculture Organization of the United Nations (FAO); 2013.

5. Gerber PJ, Steinfeld H, Henderson B, Mottet A, Opio C, Dijkman J, Falcucci A, Tempio G. Tackling climate change through livestock - a global assessment of emissions and mitigation opportunities. Rome, Italy: Food and Agriculture Organization of the United Nations (FAO); 2013.

6. EPA. Inventory of U.S. Greenhouse gas emissions and sinks. Washington, DC USA: Environmental Protection Agency (EPA); 2011.

7. EPA. Global mitigation of non-co2 gases. Washington, DC, USA: Environmental Protection Agency (EPA); 2006.

8. Stams AJ, Plugge CM. Electron transfer in syntrophic communities of anaerobic bacteria and archaea. Nat Rev Microbiol. 2009;7:568-77.

9. Ellis JL, Dijkstra J, Kebreab E, Bannink A, Odongo NE, McBride BW, France J. Aspects of rumen microbiology central to mechanistic modelling of methane production in cattle. J Agric Sci. 2008;146:213-33.

10. Wolin MJ. In: Mcdonald IW, Warner ACl, editors. Interactions between the bacterial species of the rumen. : Digestion and metabolism in the ruminants. Armidale, Australia: The University of new England; 1975.

11. Carroll EJ, Hungate RE. Formate dissimilation and methane production in bovine rumen contents. Arch Biochem Biophys. 1955;56:525-36.

12. Hungate RE. Formate as an intermediate in bovine rumen fermentation. J Bacteriol. 1970;102:389-97.

13. Liu YC, Whitman WB. In: Wiegel J, Maier RJ, Adams MWW, editors. Metabolic, phylogenetic, and ecological diversity of the methanogenic archaea, in Incredible anaerobes: From physiology to genomics to fuels; 2008. p. 171-89.

14. Thauer RK, Kaster AK, Seedorf H, Buckel W, Hedderich R. Methanogenic archaea: ecologically relevant differences in energy conservation. Nat Rev Microbiol. 2008;6:579-91.

15. Morgavi DP, Forano E, Martin C, Newbold CJ. Microbial ecosystem and methanogenesis in ruminants. Animal. 2010;4:1024-36.

16. Neill AR, Grime DW, Dawson RM. Conversion of choline methyl groups through trimethylamine into methane in the rumen. Biochem J. 1978;170:529-35.

17. Janssen PH, Kirs M. Structure of the archaeal community of the rumen. Appl Environ Microbiol. 2008:74:3619-25.

18. Milich $\mathrm{L}$. The role of methane in global warming: where might mitigation strategies be focused? Glob Environ Chang. 1999;9:179-201.

19. Beauchemin KA, Kreuzer M, O'Mara F, McAllister TA. Nutritional management for enteric methane abatement: a review. Aust J Exp Agric. 2008:48:21-7.

20. Eckard RJ, Grainger C, de Klein CAM. Options for the abatement of methane and nitrous oxide from ruminant production: a review. Livest Sci. 2010;130:47-56.

21. Martin C, Morgavi DP, Doreau M. Methane mitigation in ruminants: from microbe to the farm scale. Animal. 2010;4:351-65.

22. Benchaar C, Pomar C, Chiquette J. Evaluation of dietary strategies to reduce methane production in ruminants: a modelling approach. Can J Anim Sci. 2001;81:563-74. 
23. Mosier AR, Duxbury JM, Freney JR, Heinemeyer O, Minami K, Johnson DE. Mitigating agricultural emissions of methane. Clim Chang. 1998;40:39-80.

24. Boadi DA, Wittenberg KM. Methane production from dairy and beef heifers fed forages differing in nutrient density using the Sulphur hexafluoride (sf6) tracer gas technique. Can J Anim Sci. 2002;82:201-6.

25. Beever DE, Dhanoa MS, Losada HR, Evans RT, Cammell SB, France J. The effect of forage species and stage of harvest on the processes of digestion occurring in the rumen of cattle. Br J Nutr. 1986;56:439-54.

26. Hammond KJ, Burke JL, Koolaard JP, Muetzel S, Pinares-Patiño CS, Waghorn GC. Effects of feed intake on enteric methane emissions from sheep fed fresh white clover (trifolium repens) and perennial ryegrass (lolium perenne) forages. Anim Feed Sci Technol. 2013;179:121-32.

27. Archimède $H$, Eugène $M$, Marie Magdeleine $C$, Boval $M$, Martin $C$, Morgavi DP, Lecomte P, Doreau M. Comparison of methane production between c3 and c4 grasses and legumes. Anim Feed Sci Technol. 2011;166-167:59-64.

28. Boadi DA, Wittenberg KM, Scott SL, Burton D, Buckley K, Small JA, Ominski $\mathrm{KH}$. Effect of low and high forage diet on enteric and manure pack greenhouse gas emissions from a feedlot. Can J Anim Sci. 2004;84:445-53.

29. Tamminga S, Bannink A, Dijkstra J, Zom R. Feeding strategies to reduce methane loss in cattle. Lelystad: The Netherlands: Animal Nutrition and Animal Sciences Group, Wageningen UR; 2007, Report.

30. O'Mara FP, Fitzgerald JJ, Murphy JJ, Rath M. The effect on milk production of replacing grass silage with maize silage in the diet of dairy cows. Livest Prod Sci. 1998;55:79-87.

31. Hassanat F, Gervais R, Julien C, Massé DI. Replacing alfalfa silage with corn silage in dairy cow diets: effects on enteric methane production, ruminal fermentation, digestion, n balance, and milk production. J Dairy Sci. 2013;96:4553-67.

32. Ferris CP, Gordon FJ, Patterson DC, Porter MG, Yan T. The effect of genetic merit and concentrate proportion in the diet on nutrient utilization by lactating dairy cows. J Agric Sci. 1999;132:483-90.

33. Lovett D, Lovell S, Stack L, Callan J, Finlay M, Conolly J, O'Mara FP. Effect of forage/concentrate ratio and dietary coconut oil level on methane output and performance of finishing beef heifers. Livest Prod Sci. 2003;84:135-46.

34. Johnson KA, Johnson DE. Methane emissions from cattle. J Anim Sci. 1995; 73:2483-92.

35. Beauchemin KA, McAllister TA, McGinn SM. Dietary mitigation of enteric methane from cattle. CAB Reviews, vol. 4: Perspectives in Agriculture, Veterinary Science, Nutrition and Natural Resources; 2009. p. 1-18.

36. Murphy MR, Baldwin RL, Koong LJ. Estimation of stoichiometric parameters for rumen fermentation of roughage and concentrate diets. J Anim Sci. 1982:55:411-21.

37. Kessel JAS, Russell JB. The effect of ph on ruminal methanogenesis. FEMS Microbiol Ecol. 1996:20:205-10.

38. Finlay BJ, Esteban G, Clarke KJ, Williams AG, Embley TM, Hirt RP. Some rumen ciliates have endosymbiotic methanogens. FEMS Microbiol Lett. 1994;117:157-61.

39. Ørskov ER. Starch digestion and utilization in ruminants. J Anim Sci. 1986;63: 1624-33.

40. Harmon DL, Yamka RM, Elam NA. Factors affecting intestinal starch digestion in ruminants: a review. Can J Anim Sci. 2004;84:309-18.

41. Hindrichsen IK, Wettstein HR, Machmuller A, Jorg B, Kreuzer M. Effect of the carbohydrate composition of feed concentratates on methane emission from dairy cows and their slurry. Environ Monit Assess. 2005;107:329-50.

42. Hindrichsen IK, Kreuzer M. High methanogenic potential of sucrose compared with starch at high ruminal ph. J Anim Physiol Anim Nutr. 2009;93:61-5.

43. Boadi D, Benchaar C, Chiquette J, Masse D. Mitigation strategies to reduce enteric methane emissions from dairy cows: update review. Can J Anim Sci. 2004;84:319-35.

44. Giger-Reverdin S, Morand-Fehr P, Tran G. Literature survey of the influence of dietary fat composition on methane production in dairy cattle. Livest Prod Sci. 2003:82:73-9.

45. Jenkins TC. Lipid-metabolism in the rumen. J Dairy Sci. 1993;76:3851-63.

46. Grainger $C$, Beauchemin KA. Can enteric methane emissions from ruminants be lowered without lowering their production? Anim Feed Sci Technol. 2011:166-67:308-20.

47. Doreau M, Chilliard Y. Digestion and metabolism of dietary fat in farm animals. Br J Nutr. 1997;78(Suppl 1):S15-35.

48. Castillo C, Benedito JL, Mendez J, Pereira V, Lopez-Alonso M, Miranda M, Hernandez J. Organic acids as a substitute for monensin in diets for beef cattle. Anim Feed Sci Technol. 2004;115:101-16.

49. Newbold CJ, Lopez S, Nelson N, Ouda JO, Wallace RJ, Moss AR. Propionate precursors and other metabolic intermediates as possible alternative electron acceptors to methanogenesis in ruminal fermentation in vitro. $\mathrm{Br} \mathrm{J}$ Nutr. 2005:94:27-35.

50. McAllister TA, Newbold CJ. Redirecting rumen fermentation to reduce methanogenesis. Aust J Exp Agric. 2008:48:7-13.

51. Kolver ES. Fumarate reduces methane production from pasture fermented in continuous culture: proceedings of the New Zealand society of animal production: New Zealand Society of Animal Production; 2004.

52. Ungerfeld EM, Kohn RA, Wallace RJ, Newbold CJ. A meta-analysis of fumarate effects on methane production in ruminal batch cultures. J Anim Sci. 2007:85:2556-63.

53. Beauchemin K, McGinn S. Methane emission from beef cattle: effects of fumaric acid, essential oil and canola oil. J Anim Sci. 2006;84:1489-96.

54. Greathead $\mathrm{H}$. Plants and plant extracts for improving animal productivity. Proc Nutr Soc. 2003;62:279-90.

55. Burt S. Essential oils: their antibacterial properties and potential applications in foods - a review. Int J Food Microbiol. 2004;94:223-53.

56. Benchaar C, Calsamiglia S, Chaves AV, Fraser GR, Colombatto D, McAllister TA, Beauchemin KA. A review of plant-derived essential oils in ruminant nutrition and production. Anim Feed Sci Technol. 2008:145:209-28.

57. Benchaar C, Greathead H. Essential oils and opportunities to mitigate enteric methane emissions from ruminants. Anim Feed Sci Technol. 2011; 166-67:338-55.

58. Jouany JP, Morgavi DR. Use of 'natural' products as alternatives to antibiotic feed additives in ruminant production. Animal. 2007;1:1443-66.

59. Newbold CJ, Mclntosh FM, Williams P, Losa R, Wallace RJ. Effects of a specific blend of essential oil compounds on rumen fermentation. Anim Feed Sci Technol. 2004;114:105-12.

60. McGuffey RK, Richardson LF, Wilkinson JID. Ionophores for dairy cattle: current status and future outlook. J Dairy Sci. 2001;84:E194-203.

61. Hook SE, Northwood KS, Wright ADG, McBride BW. Long-term monensin supplementation does not significantly affect the quantity or diversity of methanogens in the rumen of the lactating dairy cow. Appl Environ Microbiol. 2009;75:374-80.

62. Patra AK. Enteric methane mitigation technologies for ruminant livestock: a synthesis of current research and future directions. Environ Monit Assess. 2012:184:1929-52.

63. McGinn SM, Beauchemin KA, Coates T, Colombatto D. Methane emissions from beef cattle: effects of monensin, sunflower oil, enzymes, yeast, and fumaric acid. J Anim Sci. 2004;82:3346-56.

64. Odongo NE, Bagg R, Vessie G, Dick P, Or-Rashid MM, Hook SE, Gray JT, Kebreab E, France J, McBride BW. Long-term effects of feeding monensin on methane production in lactating dairy cows. J Dairy Sci. 2007;90:1781-8.

65. Guan H, Wittenberg KM, Ominski KH, Krause DO. Efficacy of ionophores in cattle diets for mitigation of enteric methane. J Anim Sci. 2006;84:1896-906.

66. Moss AR, Jouany JP, Newbold J. Methane production by ruminants: its contribution to global warming. Ann Zootech. 2000;49:231-53.

67. Lopez S, Mclntosh E, Wallace RJ, Newbold CJ. Effect of adding acetogenic bacteria on methane production by mixed rumen microorganisms. Anim Feed Sci Technol. 1999:78:1-9.

68. McAllister TA, Beauchemin KA, Alazzeh AY, Baah J, Teather RM, Stanford K Review: the use of direct fed microbials to mitigate pathogens and enhance production in cattle. Can J Anim Sci. 2011;91:193-211.

69. Newbold CJ, Rode LM. Dietary additives to control methanogenesis in the rumen. Int Congr Ser. 2006;1293:138-47.

70. Beauchemin KA, Colombatto D, Morgavi DP, Yang WZ. Use of exogenous fibrolytic enzymes to improve feed utilization by ruminants. J Anim Sci. 2003:81:E37-47

71. Eun JS, Beauchemin KA. Assessment of the efficacy of varying experimental exogenous fibrolytic enzymes using in vitro fermentation characteristics. Anim Feed Sci Technol. 2007;132:298-315.

72. Kristjansson J, Schönheit P, Thauer R. Different ks values for hydrogen of methanogenic bacteria and sulfate reducing bacteria: an explanation for the apparent inhibition of methanogenesis by sulfate. Arch Microbiol. 1982;131: 278-82.

73. Leng RA. The potential of feeding nitrate to reduce enteric methane production in ruminants, in Report. Canberra ACT Australia: The Department of Climate Change, commonwealth government of Australia; 2008. Available on http://www.penambulbooks.com/Downloads/LengFinal\%20Modified\%20\%2017-9-2008.pdf

74. van Zijderveld SM, Gerrits WJJ, Apajalahti JA, Newbold JR, Dijkstra J, Leng RA, Perdok HB. Nitrate and sulfate: effective alternative hydrogen sinks for 
mitigation of ruminal methane production in sheep. J Dairy Sci. 2010;93: 5856-66.

75. van Zijderveld SM, Gerrits WJJ, Dijkstra J, Newbold JR, Hulshof RBA, Perdok HB. Persistency of methane mitigation by dietary nitrate supplementation in dairy cows. J Dairy Sci. 2011;94:4028-38.

76. Bruning-Fann CS, Kaneene JB. The effects of nitrate, nitrite, and n-nitroso compounds on animal health. Vet Hum Toxicol. 1993;35:237-53.

77. Bodas R, Prieto N, García-González R, Andrés S, Giráldez FJ, López S. Manipulation of rumen fermentation and methane production with plant secondary metabolites. Anim Feed Sci Technol. 2012;176:78-93.

78. Hristov AN, Ivan M, Neill L, McAllister TA. Evaluation of several potential bioactive agents for reducing protozoal activity in vitro. Anim Feed Sci Technol. 2003;105: 163-84.

79. Patra AK, Saxena J. Dietary phytochemicals as rumen modifiers: a review of the effects on microbial populations. Antonie Van Leeuwenhoek. 2009;96: 363-75.

80. Dorman HJD, Deans SG. Antimicrobial agents from plants: antibacterial activity of plant volatile oils. J Appl Microbiol. 2000;88:308-16.

81. Ramirez-Restrepo CA, Barry TN. Alternative temperate forages containing secondary compounds for improving sustainable productivity in grazing ruminants. Anim Feed Sci Technol. 2005;120:179-201.

82. Wallace RJ. Antimicrobial properties of plant secondary metabolites. Proc Nutr Soc. 2004;63:621-9.

83. Goel G, Makkar HP. Methane mitigation from ruminants using tannins and saponins. Trop Anim Health Prod. 2012;44:729-39.

84. Liu H, Vaddella V, Zhou D. Effects of chestnut tannins and coconut oil on growth performance, methane emission, ruminal fermentation, and microbial populations in sheep. J Dairy Sci. 2011;94:6069-77.

85. Newbold CJ, el Hassan SM, Wang J, Ortega ME, Wallace RJ. Influence of foliage from african multipurpose trees on activity of rumen protozoa and bacteria. Br J Nutr. 1997;78:237-49.

86. Patra AK, Saxena J. The effect and mode of action of saponins on the microbial populations and fermentation in the rumen and ruminant production. Nutr Res Rev. 2009;22:204-19.

87. Wright ADG, Kennedy P, O'Neill CJ, Toovey AF, Popovski S, Rea SM, Pimm $\mathrm{CL}$, Klein L. Reducing methane emissions in sheep by immunization against rumen methanogens. Vaccine. 2004;22:3976-85.

88. Williams YJ, Popovski S, Rea SM, Skillman LC, Toovey AF, Northwood KS, Wright $A D G$. A vaccine against rumen methanogens can alter the composition of archaeal populations. Appl Environ Microbiol. 2009;75:1860-6.

89. Goel G, Makkar HP, Becker K. Inhibition of methanogens by bromochloromethane: effects on microbial communities and rumen fermentation using batch and continuous fermentations. Br J Nutr. 2009; 101:1484-92.

90. Joblin KN. Ruminal acetogens and their potential to lower ruminant methane emissions. Aust J Agric Res. 1999;50:1307-13.

91. Weisbjerg MR, Terkelsen M, Hvelplund T, Madsen J. Increased productivity in tanzanian cattle production is the main approach to reduce methane emission per unit of product. in Book of Abstracts, 35th Annual scientific conference. Olasiti Garden, Arusha, Tanzania; 2012.

92. Clark H, Pinares-Patino C, de Klein C. Methane and nitrous oxide emissions from grazed grasslands, in 20th International Grassland Congress. In: McGilloway DA, editor. Grassland: A Global Resource. The Netherlands: Wageningen Academic Publishers; 2005. p. 279-93.

93. Madsen J, Lassen J, Hvelplund T, Weisbjerg MR. A fast, easy, reliable and cheap method to measure the methane production from ruminants, in Eaap publication no. 127. Wageningen: Wageningen Academic Publishers; 2010. p. 121-2.

94. Pinares-Patio CS, Ulyatt MJ, Lassey KR, Barry TN, Holmes CW. Persistence of differences between sheep in methane emission under generous grazing conditions. J Agric Sci. 2003:140:227-33.

95. Kohn RA, Boston RC. In: McNamara JP, France J, Beever DE, editors. The role of thermodynamics in controlling rumen metabolism: Modelling nutrient utilization in farm animals. Wallingford, Oxon, GBR: CABI Publishing; 2000.

96. Ungerfeld EM. A theoretical comparison between two ruminal electron sinks. Frontiers in Microbiol. 2013:4:319.

\section{Ready to submit your research? Choose BMC and benefit from:}

- fast, convenient online submission

- thorough peer review by experienced researchers in your field

- rapid publication on acceptance

- support for research data, including large and complex data types

- gold Open Access which fosters wider collaboration and increased citations

- maximum visibility for your research: over $100 \mathrm{M}$ website views per year

At BMC, research is always in progress.

Learn more biomedcentral.com/submissions 